\title{
Bazı Yulaf (Avena sativa L.) Genotiplerinin Tane Verimi, Kalite ve Tarımsal Özelliklerinin Belirlenmesi
}

\author{
*Turhan KAHRAMAN, Remzi AVCI, Cengiz KURT \\ Trakya Tarımsal Araștırma Enstitüsü, Edirne \\ *Sorumlu yazar e-posta (Corresponding author; e-mail): turhankahraman@hotmail.com
}

\begin{abstract}
Öz
Buçalıșma, Trakya Tarımsal Araștırma Enstitüsünün ıslah çalıșmaları sonucu geliștirilen yulaf genotiplerinin tane verimi, bazı kalite ve tarımsal özelliklerinin belirlenmesi amacıyla 2012-2013 üretim yıllarında Edirne ve 2013-2014 üretim sezonunda Edirne ve Kırklareli lokasyonlarında Tesadüf Blokları Deneme Desenine göre dört tekerrürlü olarak yürütülmüștür. On altı yulaf genotipinin kullanıldığı denemede, beș standart çeșit (Checota, Kırklar, Kahraman, Sebat ve Y-330) yer almıștır. Genotiplerin tane verimi, bitki boyu, olgunlașma süresi ile kalite özelliklerinden bin tane ağırlı̆ı, hektolitre ağırlığı, protein oranı, iç oranı, kavuz oranı ve elek analizi incelenmiștir. İncelenen özellikler yönünden genotipler ve lokasyonlar arasındaki farklllık istatistiki olarak önemli bulunmuștur. 2012-2013 yilı Edirne, 2013-2014 yılı Edirne ve Kırklareli lokasyonlarında genotiplerin tane verimi; 281.4-688.3, 349.1-828.0 ve 478.2-993.0 kg/da, bitki boyu; 110.8-156.0, 141.3177.5 ve 126.3-171.3 cm, olgunlașma süresi; 29-37, 33-39 ve 36-43 gün, 1000 tane ağırlığl; 18.7-31.6, 19.638.7 ve 22.7-45.0 g, hektolitre ağırlığl; 43.9-55.5, 45.7-60.4 ve 44.0-60.7 kg/hl, protein oranl; \%12.7-15.2, $\% 10.9-14.3$ ve \%9.0-11.3, tane iç oranı \%56.1-75.5, 62.5-77.7 ve \%61.5-78.4, kavuz oranı; \%24.5-43.6, \%20.0-37.3 ve \%21.6-38.2 ve 2.2 mm elek üstü \%25.1-81.9, \%17.3-93.7 ve \%28.3-95.5 arasında değișim göstermiștir. Tane verimi yönünden lokasyon ortalamalarına göre $734.8 \mathrm{~kg} / \mathrm{da}$ ile $10,728.1 \mathrm{~kg} / \mathrm{da}$ ile $7 \mathrm{ve}$ $695.6 \mathrm{~kg} / \mathrm{da}$ ile 15 nolu genotipler en yüksek tane verimine ulașmıștır. Standart çeșitlerden $690.2 \mathrm{~kg} / \mathrm{da}$ ile Kırklar ve $686.3 \mathrm{~kg} / \mathrm{da}$ ile Kahraman en yüksek tane verimine ulașırken, $372.1 \mathrm{~kg} / \mathrm{da}$ ile Y-330 ve 397.0 $\mathrm{kg} / \mathrm{da}$ ile Checota çeșitleri ise en düșük tane verimine ulașmıștır. İncelenen özellikler yönünden öne çıkan kısa boylu ve yatmaya dayanıklı 15 nolu hat, 2014 yılında tescile verilmiștir.
\end{abstract}

Anahtar Kelimeler: Yulaf (Avena sativa L.), tane verimi, kalite, tarımsal özellik

\section{Determination of Grain Yield, Quality and Agronomic Traits of Some Oat (Avena sativa L.) Genotypes}

Abstract

This study was carried out at Edirne in 2012-2013 and at Edirne and Kırklareli locations in 2013-2014. Sixteen oat genotypes, and five standard varieties (Checota, Kırklar, Kahraman, Sebat and Y-330) were planted as research materials. It was aimed to determine grain yield, quality characteristics and agronomic traits of some oat genotypes developed by Thrace Agricultural Research Institute. This study was conducted in randomized complete block design technique with four replicates. The traits such as grain yield, plant height, ripening period and thousand grain weight, test weight, protein ratio, groat percentage, husk rate and kernel plumpness ( $P$. sieved $2.2 \mathrm{~mm}$ slotted) quality parameter performances of genotypes were investigated. The variations among oat lines and locations for investigated properties were significant. The grain yield, plant height, ripening period, thousand grain weight, test weight, protein percent age, groat percent age, husk rate and kernel plumpness (P. sieved $2.2 \mathrm{~mm}$ slotted) of oat lines ranged between; 281.4-688.3, 349.1-828.0 and 478.2-993.0 kg/da, 110.8-156.0, 141.3-177.5 and 126.3-171.3 cm, 29-37, 33-39 and 36-43 day, 18.7-31.6, 19.6-38.7 and 22.7-45.0 g, 43.9-55.5, 45.7-60.4 and 44.0-60.7 kg/hl, 12.7-15.2, 10.9-14.3 and 9.0-11.3\%, 56.1-75.5, 62.5-77.7 and 61.5-78.4\%, 24.5-43.6, 20.0-37.3 and 21.6-38.2\%, 25.1-81.9, 17.3-93.7\% and 28.3-95.5\% at Edirne in 2012-13 and at Edirne and Kırklareli Locations in 2013-14 respectively. The oat line 10 had the highest mean grain yield with $734.8 \mathrm{~kg} / \mathrm{da}$ and followed by oat line 7 with $728.1 \mathrm{~kg} / \mathrm{da}$ and oat line 15 with $695.6 \mathrm{~kg} / \mathrm{da}$ in terms of grain yield in all locations. In the control varieties, Kırklar variety had the highest grain yield with $690.2 \mathrm{~kg} / \mathrm{da}$ followed by Kahraman variety with $686.3 \mathrm{~kg} / \mathrm{da}$ while the lowest grain yield was obtained from the Y-330 variety with $372.1 \mathrm{~kg} / \mathrm{da}$ and Checota variety with $397.0 \mathrm{~kg} / \mathrm{da}$. Short oat line 15, having short plant height and lodging resistance registered as a cultivar candidate to the Seed Registration and Certification Institution. Height and lodging resistance of oat line 15 was offered to registration in 2014.

Keywords: Oat (Avena sativa L.), grain yield, quality, agronomic properties 


\section{Giriș}

Y ulaf (Avena sativa L.), dünyada insan beslenmesinde ve hayvan yemi olarak kullanılan bir tahıl bitkisidir. Diğer tahıllarla karșılaștırıldığında, serin, yağıșlı iklimler ve düșük verimli toprakları da içeren marjinal alanlarda yetiștirilmektedir (Hoffmann, 1995). Ayrıca, yulaf, uzun gün rejimli, kısa sezonlarda, hızlı bir șekilde çiçeklenir ve olgunlașır, bu yüzden, İskandinav ülkelerinde, yulaf önemli bir bitkidir (Buerstmayr et al., 2007). Son yıllarda, insan beslenmesindeki yulaf tüketimi yulafın besin değeri sayesinde artıș göstermiștir (Food and Drug Administration, 1997). Yulaf bitkisi hem insan gıdası olarak, hem de hayvan beslemede oldukça önemli olmasına rağmen, yulafın soğuğa ve kurağa dayanıklıı̆ııın düșük olmasının yanı sıra tane dökme, yatma ve eș zamanlı olgunlașmama gibi sorunlardan dolayı, yulaf üretimi ülkemizde sınırlı kalmıștır (Dumlupınar, 2010). Ülkemizde ekilen yulafın yarısı tane olarak yarısı da yeșil ot amaçlı olarak yetiștirilmektedir. Yulaf, 2016 yılında 994.379 da alanda tane olarak, 868.000 da alanda yeșil ot olarak ekilmiștir (Anonim, 2017a).

Ülkemizde 2013 yllında sadece beș tescilli yulaf çeșidi bulunurken, 2017 yllında 3'ü özel, 11'i kamu kurulușuna ait toplam 14 yulaf çeșidi (Checota, Faikbey, Seydișehir, Sebat, Yeniçeri, Sarı, Fetih, Kırklar, Kahraman, Haskara, Albatros, Bc Marta, Diriliș ve Arslanbey) tescillenerek çeșit sayısında önemli artıș sağlanmıștır (Anonim, 2013; 2017b).

Tamm (2003), ve Buerstmyr et al. (2007) yaptıkları çalıșmalarda iklim șartlarııın (özellikle sıcaklık ve yağıș miktarı ve dağılımı) yulafta tane verimi, verim unsurları ve kalite özellikleri üzerine önemli derecede etkisinin olduğunu bildirmișlerdir. Yulafta hektolitre ağırlığı ile iç oranı arasında yüksek bir ilișki belirlenmiștir (Doehlert et al., 2001; Peterson et al., 2005).

Araștırmada ıslah çalıșmaları sonucu geliștirilen 11 hat ile 5 standart çeșidin tane verimi, bazı kalite ve tarımsal özelliklerinin belirlenmesi amaçlanmıștır. Bu kapsamda iki yıl süreyle 3 lokasyonda genotiplerin tane verimi, bitki boyu, salkım çıkarma süresi, bin tane ağırlığı, hektolitre ağırlığı, iç oranı, kavuz oranı ve protein oranları incelenmiștir.

\section{Materyal ve Yöntem}

2012-2013 üretim yilında Edirne, 2013-2014 üretim yılında Edirne ve Kırklareli lokasyonlarında yürütülen bu araștırma beș sandart çeșit (Checota, Kirklar, Kahraman, Sebat ve Y-330) ile 11 yulaf hattından kurulmuștur. Deneme, Tesadüf Blokları Deneme Desenine göre dört tekerrürlü olarak yürütülmüștür.

Ekim, $\mathrm{m}^{2}$ 'ye 500 adet tohum olacak șekilde $7 \mathrm{~m} \times 1 \mathrm{~m}=7 \mathrm{~m}^{2}$ parsellere özel ekim mibzeriyle yapılmıștır. Hasatta ise parseller $6 \mathrm{~m} \times 1 \mathrm{~m}=6$ $\mathrm{m}^{2}$ alan üzerinden değerlendirilmiștir.

\section{Bulgular ve Tartıșma}

Genotiplerin tane verimi ve bitki boyu ile ilgili veriler Çizelge-1'de verilmiștir. Genotiplerin tane verimi ve lokasyonlar arsındaki farklıık istatistiki olarak önemli bulunmuștur.

En yüksek tane verimi $759.1 \mathrm{~kg} / \mathrm{da}$ ile Kırklareli lokasyonunda alınırken, $541.9 \mathrm{~kg} /$ da ile 2012-2013 üretim sezonundaki Edirne lokasyonundan alınmıștır. 2012-2013 üretim yılı Edirne lokasyonunda genotiplerin tane verimi $281.4-688.3 \mathrm{~kg} / \mathrm{da}$ arasında olmuștur. Tane verimi $688.3 \mathrm{~kg} / \mathrm{da}$ ile 10 nolu genotip en yüksek verime ulașırken, $281.4 \mathrm{~kg} / \mathrm{da}$ ile Checota çeșidi en düșük verime ulașmıștır. 2013-2014 üretim yılında Edirne lokasyonunda genotiplerin tane verimi $349.1-828.0 \mathrm{~kg} / \mathrm{da}$ arasında olmuștur. Tane verimi $828.0 \mathrm{~kg} / \mathrm{da}$ ile 7 nolu genotip en yüksek verime ulașırken, $349.1 \mathrm{~kg} / \mathrm{da}$ ile Y-330 çeșidi en düșük verime ulașmıștır. 2013-2014 yll Kırklareli'nde ise genotiplerin tane verimi $478.2-993.0 \mathrm{~kg} / \mathrm{da}$ arasında olmuștur. Tane verimi $993.0 \mathrm{~kg} / \mathrm{da}$ ile 7 nolu genotip en yüksek verime ulașirken, $478.2 \mathrm{~kg} / \mathrm{da}$ ile Y-330 çeșidi en düșük verime ulașmıștır. Üç lokasyon ortalamasına göre, $734.8 \mathrm{~kg} / \mathrm{da}$ tane verimi ile 10 nolu genotip en yüksek verime ulașırken, $372.1 \mathrm{~kg} / \mathrm{da}$ ile Y-330 çeșidi en düșük verime ulașmıștır. Yaptığımız çalıșmaya benzer șekilde tane verimi yönünden genotipler arasındaki farkların önemli olduğunu belirtmișlerdir (Yağbasanlar ve ark., 1991; Sarı ve İmamoğlu. 2011; Sarı ve ark., 2012. Kahraman ve ark., 2012; 2013; 2015). Tane verimi yönünden (Gül ve ark., 1999; İnan ve ark., 2005; Kara ve ark., 2007; Mut ve ark., 2011; Erbaș ve Mut 2013; Dumlupınar ve ark., 2013)'nın sonuçları farklılık göstermiștir. Genotip ve deneme șartlarının farklı olmasından dolayı verimler arasında farklılıklar gözlemlenmiștir. 
Çizelge 1. On altı yulaf genotipin üç lokasyondaki tane verimi ve bitki boyu ortalama değerleri ve gruplar Table 1. Mean performance and LSD ranks of 16 oat genotypes for grain yield and plant heigth at 3 locations

\begin{tabular}{|c|c|c|c|c|c|c|c|c|}
\hline & & \multicolumn{4}{|c|}{ Tane Verimi (kg/da) } & \multicolumn{3}{|c|}{ Bitki Boyu $(\mathrm{cm})$} \\
\hline & & $2012-13$ & \multicolumn{2}{|c|}{ 2013-14 } & & \multirow{2}{*}{$\begin{array}{c}2012-13 \\
\text { Edirne }\end{array}$} & \multicolumn{2}{|c|}{ 2013-14 } \\
\hline No & Çeșit ve Pedigri & Edirne & Edirne & K. eli & Ortalama & & Edirne & K. eli \\
\hline 10 & FL04144-0BD-0T-0T-5T-0T & $688.3 \mathrm{a}$ & $741.4 \mathrm{ab}$ & $821.5 \mathrm{bc}$ & $734.8 \mathrm{a}$ & $118.0 \mathrm{gh}$ & $157.5 \mathrm{~d}-\mathrm{f}$ & $145.0 \mathrm{e}-\mathrm{g}$ \\
\hline 7 & IL 3555-0BD-0T-5T-0T & $545.8 \mathrm{~cd}$ & $828.0 \mathrm{a}$ & $993.0 \mathrm{a}$ & $728.1 \mathrm{a}$ & $139.3 \mathrm{c}$ & $177.5 \mathrm{a}$ & $167.5 \mathrm{a}$ \\
\hline 15 & FL0557-0BD-0T-0T-5T-0T & $647.3 \mathrm{ab}$ & $737.6 \mathrm{ab}$ & $750.1 \mathrm{c}-\mathrm{e}$ & $695.6 \mathrm{ab}$ & $129.5 \mathrm{e}$ & $148.8 \mathrm{gh}$ & $132.5 \mathrm{ij}$ \\
\hline 3 & Bw 103-0BD-0T-7T-0T & $611.3 \mathrm{a}-\mathrm{d}$ & 691.4 bc & $866.3 \mathrm{~b}$ & $695.1 \mathrm{ab}$ & $119.3 \mathrm{~g}$ & $146.3 \mathrm{hl}$ & $136.3 \mathrm{hl}$ \\
\hline 2 & KIRKLAR (ST) & 663.9 a & 649.7 bc & $783.3 \mathrm{bc}$ & $690.2 \mathrm{a}-\mathrm{c}$ & $133.3 \mathrm{~d}$ & $162.5 \mathrm{~cd}$ & $151.3 \mathrm{de}$ \\
\hline 5 & KAHRAMAN (ST) & $626.1 \mathrm{a}-\mathrm{c}$ & $684.5 \mathrm{bc}$ & $808.4 \mathrm{bc}$ & $686.3 \mathrm{a}-\mathrm{c}$ & $131.0 \mathrm{de}$ & $157.5 \mathrm{~d}-\mathrm{f}$ & $142.5 \mathrm{f}-\mathrm{h}$ \\
\hline 4 & Bw 1103-0BD-0T-3T-0T & $554.8 b-d$ & $710.1 \mathrm{ab}$ & $796.3 \mathrm{bc}$ & $654.0 \mathrm{~b}-\mathrm{d}$ & $122.8 \mathrm{f}$ & $150.0 \mathrm{gh}$ & $140.0 \mathrm{gh}$ \\
\hline 9 & Bw 1103-0BD-0T-6T-0T & $535.5 \mathrm{~cd}$ & 674.9 bc & $810.0 \mathrm{bc}$ & $639.0 \mathrm{~b}-\mathrm{d}$ & 110.8 । & $150.0 \mathrm{gh}$ & $137.5 \mathrm{hı}$ \\
\hline 6 & Ave.98.01-0BD-0T-9T-0T & $555.0 b-d$ & 655.4 bc & $767.8 \mathrm{~cd}$ & $633.3 \mathrm{~b}-\mathrm{e}$ & $116.0 \mathrm{~h}$ & 141.3 I & $126.3 \mathrm{j}$ \\
\hline 11 & FL04146-0BD-0T-0T-2T-0T & $635.0 \mathrm{a}-\mathrm{c}$ & $417.6 \mathrm{fg}$ & $827.8 \mathrm{bc}$ & $628.8 \mathrm{c}-\mathrm{e}$ & $123.0 \mathrm{f}$ & $160.0 \mathrm{de}$ & $147.5 d-f$ \\
\hline 13 & FL04167-0BD-0T-0T-10T-0T & $517.3 d$ & $629.8 b-d$ & 792.9 bc & $614.3 \mathrm{de}$ & $116.0 \mathrm{~h}$ & $153.8 \mathrm{e}-\mathrm{g}$ & $142.5 \mathrm{f}-\mathrm{h}$ \\
\hline 16 & FL0568-0BD-0T-0T-5T-0T & $602.6 \mathrm{a}-\mathrm{d}$ & $470.5 e-g$ & $687.1 \mathrm{de}$ & $590.7 \mathrm{de}$ & $128.0 \mathrm{e}$ & $162.5 \mathrm{~cd}$ & $153.8 \mathrm{~cd}$ \\
\hline 14 & FL0557-0BD-0T-0T-3T-0T & $510.9 d$ & $501.0 \mathrm{~d}-\mathrm{f}$ & $759.3 \mathrm{~cd}$ & $570.5 \mathrm{e}$ & $117.8 \mathrm{gh}$ & $151.3 \mathrm{f}-\mathrm{h}$ & $141.3 \mathrm{f}-\mathrm{h}$ \\
\hline 12 & SEBAT (ST) & $365.1 \mathrm{e}$ & $569.3 \mathrm{c}-\mathrm{e}$ & $669.2 \mathrm{e}$ & $492.2 \mathrm{f}$ & $137.0 \mathrm{c}$ & 168.8 bc & $165.0 \mathrm{ab}$ \\
\hline 1 & CHECOTA (ST) & $281.4 \mathrm{e}$ & 491.4 ef & $533.8 \mathrm{f}$ & $397.0 \mathrm{~g}$ & $156.0 \mathrm{a}$ & $173.8 \mathrm{ab}$ & $171.3 \mathrm{a}$ \\
\hline 8 & Y-330 (ST) & $330.5 \mathrm{e}$ & $349.1 \mathrm{~g}$ & $478.2 \mathrm{f}$ & $372.1 \mathrm{~g}$ & $149.5 \mathrm{~b}$ & $152.5 \mathrm{f}-\mathrm{h}$ & $158.8 \mathrm{bc}$ \\
\hline & Lok. Ort. & $541.9 \mathrm{c}$ & $612.6 \mathrm{~b}$ & $759.1 \mathrm{a}$ & 637.9 & 127.9 & 157.1 & 147.4 \\
\hline & LSD & 101.5 & 131.2 & 85.8 & 64.9 & 3.13 & 6.45 & 6.38 \\
\hline & CV (\%) & 13.16 & 15.04 & 7.94 & 11.87 & 1.72 & 2.88 & 3.04 \\
\hline
\end{tabular}

Genotiplerin bitki boyları 110.8-177.5 cm arasında değișmiștir. Birinci yıl Edirne lokasyonu kurak geçtiğinden, bitki boyları ikinci yıldaki lokasyonlardan daha kısa olmuștur. Yulaf sapı ince olup boy uzun olduğunda yatma sorunuyla karșılașılmaktadır. Uzun boylu ve ince saplı çeșitler yatmaya meyilli olduğundan kısa boylu ve sağlam saplı olanlar tercih edilmelidir. Bitki boyları yönünden elde ettiğimiz sonuçlar, İnan ve ark. (2005), Kara ve ark. (2007), Sarı ve İmamoğlu (2011), Kahraman ve ark. (2012), Dumlupınar ve ark. (2013), Kahraman ve ark. (2015)'nın bulgularıla benzerlik gösterirken, Gül ve ark. (1999) ile Erbaș ve Mut (2013)'un çalıșmalarında, daha kurak bölgede ve kullanılan genotiplerden dolayı sonuçlar farklı olmuștur.

Genotiplerin bin tane ağırlığı 18.7-45.0 g arasında değișmiștir. 2012-2013 üretim yılında genotiplein bin tane ağırlıkları 2013-14 yılındaki lokasyonlardan farklı olmuștur. İkinci yılda ise genotiplerin bin tane ağırlıkları benzerlik göstermiștir. İnsan beslemesinde kullanılacak yulaflarda bin tane ağırlığının 26 g'dan yüksek olması istenmektedir. Bin tane ağırlığı yönünden elde ettiğimiz sonuçlar Gül ve ark. (2004), Kara ve ark. (2007), Sarı ve İmamoğlu (2011), Sarı ve ark. (2012), Kahraman ve ark. (2012), Kahraman ve ark. (2013), Erbaș ve Mut (2013), Dumlupınar ve ark. (2013), Kahraman ve ark. (2015)'nın bulgularıyla benzerlik göstermiștir.

Genotiplerin hektolitre ağırığı 43.9-60.4 kg arasında değișmiștir. Tane verimi ve 1000 tane ağırlığında olduğu gibi genotiplerin hektolitre ağırlıkları 1. yıl 2. yıl sonuçlarından daha düșük olurken, ikinci yılda lokasyonlardaki genotiplerin değerleri benzerlik göstermiștir. Sarı ve İmamoğlu (2011), Sarı ve ark. (2012), Kahraman ve ark. (2012); Kahraman ve ark. (2013). Kahraman ve ark. (2015)'nın çalıșma sonuçları benzerlik gösterirken, Mut ve ark. (2011) ile Erbaș ve Mut (2013)'ın çalıșmaları farklılık göstermiștir. Genotiplerin genetik yapısı hektolitre ağırlığı üzerine etkisi çevreden daha fazla olup kullanılan genotiplerin hektolitre ağılıklarından dolayı sonuçlar farklı olmuștur.

Yulaf genotiplerin $2.2 \mathrm{~mm}$ elek üstü değerleri \%17.3-95.5 arasında değișim göstermiștir. Lokasyonlar arasında elek değerlerinde farklılıklar olmuștur. En yüksek elek değerleri Kırklareli lokasyonunda olurken en düșük değerler ise 1. yıldaki Edirne lokasyonunda olmuștur. Çeșitler içerisinde en yüksek elek değerine Kahraman çeșidinde ulașılırken en düșük değere ise bin tane ağırlığı en az olan Sebat çeșidinde ulașılmıștır. Elek değerleri tane iriliği ile ilișkili olup bin tane ağırlığı yüksek 
genotiplerin $2.2 \mathrm{~mm}$ elek üstü değerleri de yüksek olmaktadır. Tane irilikleri tohumculuk açısından da önemlidir. Sertifikalı tohum üretiminde tohumların selektörden geçirme zorunluluğu olduğundan küçük taneli çeșitlerin tohumlarının elenmesinde selektörde tohum kayıpları fazla olmaktadır. Ayrıca küçük taneli çeșitlerin selektörleme ișlemlerinde zorluklar yașanmaktadır.

Genotiplerin tane iç oranı \%56.178.4 arasında değișmiștir. Genotiplerin lokasyonlardaki tane iç oranları benzerlik göstermiștir. İnsan beslenmesinde kullanılacak yulafların iç oranın fazla kavuz oranın ise az olması istenmektedir. Gıda sanayicisi kaliteli ürün elde edebilmek için kavuz oranı düșük, kavuzu kolay ayrılabilir ve randımanı yüksek yulaf talep etmektedir. Tane iç oranı yönünden elde ettiğimiz sonuçlar Erbaș ve Mut (2013), Kahraman ve ark. (2016)'nın bulgularıyla benzerlik göstermiștir.

Genotiplerin kavuz oranı \%20.0-38.2 arasında değișmiștir. Genotiplerin ortalama kavuz oranları arasında benzer sonuçlar elde edilmiștir. İnsan beslenmesinde kullanılacak yulafların kavuz oranı düșük ve kavuzu kolay soyulabilmelidir. Kavuz oranı yönünden elde ettiğimiz sonuçlar Sarı ve ark. (2012) ile Kahraman ve ark. (2017)'nın bulgularıyla benzerlik göstermiștir.

Genotiplerin protein oranı \%9.0-15.2 arasında değișmiștir. Kırklareli lokasyonundaki genotiplerin ortalama potein oranı diğer iki lokasyondan oldukça düșük olmuștur. Benzer lokasyonların ortalama değerleri $\% 14.3$ ve \%14.4 olurken Kırklareli lokasyonunda \%10.4 olmuștur. Amaç ister hayvan yemi isterse insan beslenmesi olsun, geliștirilecek yulafların protein miktarının yüksek olması istenmektedir.

Protein oranı yönünden elde ettiğimiz sonuçlar Yıldız ve ark. (2012), Kahraman ve ark. (2012), Erbaș ve Mut (2013), Kahraman ve ark. (2015), Kahraman ve ark. (2016)'nın bulgularıyla benzerlik gösterirken, Sarı ve ark. (2012) farklı sonuçlar bulmușlardır. Yulafın kalitesi bitkinin yetiștirildiği ekolojik koșullar, çeșit ve hasat sonrası ișlemler gibi pek çok faktöre bağlı olarak değișir. Daha önce yapılan çalıșmalarda çeșitlerin verim ve kalite özelliklerinin çeșit ve çevreye göre değiștiği belirtilmiștir (Tamm, 2003; Inan ve ark., 2005; Kara ve ark., 2005; Buerstmyr et al., 2007; Özbaș ve ark., 2009).

Çizelge 2. On altı yulaf genotipin üç lokasyondaki bin tane ağırlığı, hektolitre ağırlığı ve $2.2 \mathrm{~mm}$ elek üstü ortalama değerleri ve olușturdukları gruplar

Table 2. Mean performance and LSD groups of 16 oat genotypes for thousand grain weight, test weight and plumpness (P. sieved $2.2 \mathrm{~mm}$ slotted) at 3 locations

\begin{tabular}{|c|c|c|c|c|c|c|c|c|c|}
\hline & \multicolumn{3}{|c|}{ Bin Tane Ağırlığı (g) } & \multicolumn{3}{|c|}{ Hektolitre Ağırlığı (kg) } & \multicolumn{3}{|c|}{$2.2 \mathrm{~mm}$ elek üstü } \\
\hline & $2012-13$ & 20 & & $2012-13$ & 201 & -14 & $2012-13$ & & -14 \\
\hline Genotip & Edirne & Edirne & K. eli & Edirne & Edirne & K. eli & Edirne & Edirne & K. eli \\
\hline Checota & $30.9 \mathrm{~b}$ & $37.6 \mathrm{~b}$ & $36.0 \mathrm{~g}$ & 44.4 I & $49.9 \mathrm{j}$ & 44.0 I & 71.2 ef & $73.7 \mathrm{~g}$ & $78.6 \mathrm{~h}$ \\
\hline Kırklar & $30.0 \mathrm{c}$ & $35.1 \mathrm{~d}$ & $39.3 \mathrm{c}$ & $50.0 \mathrm{e}$ & $57.5 \mathrm{~cd}$ & 53.1 ef & $59.1 \mathrm{j}$ & $79.3 \mathrm{e}$ & $83.6 \mathrm{~g}$ \\
\hline 3 & $26.4 \mathrm{f}$ & $36.1 \mathrm{c}$ & $36.1 \mathrm{~g}$ & 43.9 । & 53.1 I & $51.4 \mathrm{f}-\mathrm{h}$ & $70.2 \mathrm{f}$ & $83.4 \mathrm{c}$ & 87.3 e \\
\hline 4 & $25.8 \mathrm{~g}$ & $35.2 \mathrm{~d}$ & $38.8 \mathrm{~d}$ & $48.0 \mathrm{gh}$ & $54.2 \mathrm{~h}$ & $55.1 \mathrm{de}$ & $73.7 \mathrm{~d}$ & $81.7 \mathrm{~d}$ & 86.7 ef \\
\hline Kahraman & $29.8 \mathrm{c}$ & $35.8 \mathrm{c}$ & $39.5 \mathrm{c}$ & $55.5 \mathrm{a}$ & $59.9 \mathrm{~b}$ & $59.7 \mathrm{a}$ & $79.6 \mathrm{~b}$ & $93.7 \mathrm{a}$ & $94.9 \mathrm{ab}$ \\
\hline 6 & 24.7 I & $28.9 \mathrm{~h}$ & $36.7 \mathrm{f}$ & $51.8 \mathrm{~d}$ & $57.2 \mathrm{~d}$ & $54.7 \mathrm{de}$ & $72.1 \mathrm{de}$ & $83.9 \mathrm{c}$ & $91.2 \mathrm{~d}$ \\
\hline 7 & $26.0 \mathrm{fg}$ & $33.1 \mathrm{e}$ & $39.4 \mathrm{c}$ & $49.0 \mathrm{f}$ & $55.4 \mathrm{~g}$ & $51.1 \mathrm{f}-\mathrm{h}$ & $52.8 \mathrm{k}$ & $72.5 \mathrm{~g}$ & $85.8 \mathrm{f}$ \\
\hline Y-330 & $26.1 \mathrm{fg}$ & 25.8 I & $27.9 \mathrm{j}$ & $48.4 \mathrm{fg}$ & 45.7 I & $50.7 \mathrm{gh}$ & 41.7 I & $31.2 \mathrm{~h}$ & 28.3 j \\
\hline 9 & $28.6 \mathrm{~d}$ & $37.7 \mathrm{~b}$ & $37.2 \mathrm{e}$ & $47.4 \mathrm{~h}$ & $56.1 \mathrm{f}$ & $52.7 \mathrm{fg}$ & $73.6 \mathrm{~d}$ & $83.8 \mathrm{c}$ & 86.4 ef \\
\hline 10 & $24.2 \mathrm{j}$ & $29.4 \mathrm{~g}$ & $35.6 \mathrm{~h}$ & $50.1 \mathrm{e}$ & $56.6 \mathrm{e}$ & $55.7 \mathrm{~cd}$ & $64.9 \mathrm{~h}$ & $75.5 f$ & $93.5 \mathrm{c}$ \\
\hline 11 & $25.9 \mathrm{~g}$ & $30.6 \mathrm{f}$ & 34.6 I & $53.0 \mathrm{bc}$ & 57.7 c & $57.4 \mathrm{bc}$ & $67.3 \mathrm{~g}$ & $75.6 \mathrm{f}$ & $87.4 \mathrm{e}$ \\
\hline Sebat & $18.7 \mathrm{k}$ & 19.6 j & $22.7 \mathrm{k}$ & 44.7 I & $48.4 \mathrm{k}$ & $50.2 \mathrm{~h}$ & $25.1 \mathrm{~m}$ & 17.3 I & 46.2 I \\
\hline 13 & $25.4 \mathrm{~h}$ & $30.9 \mathrm{f}$ & 34.7 I & $51.5 \mathrm{~d}$ & $60.4 \mathrm{a}$ & $59.1 \mathrm{ab}$ & 62.1 I & $78.9 \mathrm{e}$ & 86.5 ef \\
\hline 14 & $31.6 \mathrm{a}$ & $35.0 \mathrm{~d}$ & $42.3 \mathrm{~b}$ & $47.7 \mathrm{gh}$ & 53.11 & $56.6 \mathrm{~cd}$ & $81.9 a$ & $90.4 \mathrm{~b}$ & $95.3 \mathrm{a}$ \\
\hline 15 & $30.1 \mathrm{c}$ & $38.7 \mathrm{a}$ & $45.0 \mathrm{a}$ & $52.2 \mathrm{~cd}$ & $60.0 \mathrm{ab}$ & $56.6 \mathrm{~cd}$ & $76.8 \mathrm{c}$ & $92.3 \mathrm{a}$ & $93.8 \mathrm{bc}$ \\
\hline 16 & $27.4 \mathrm{e}$ & $37.3 \mathrm{~b}$ & $39.3 \mathrm{c}$ & $53.4 \mathrm{~b}$ & $60.3 \mathrm{ab}$ & $60.7 \mathrm{a}$ & 70.5 ef & $92.3 \mathrm{a}$ & $95.5 \mathrm{a}$ \\
\hline Lok. Ort. & 27.0 & 32.9 & 36.6 & 49.4 & 55.3 & 54.3 & 65.2 & 75.3 & 82.6 \\
\hline LSD & 0.42 & 0.47 & 0.40 & 0.78 & 0.43 & 2.01 & 1.86 & 1.62 & 1.15 \\
\hline CV (\%) & 1.10 & 1.00 & 0.78 & 1.11 & 0.55 & 2.60 & 2.01 & 1.51 & 0.98 \\
\hline
\end{tabular}


Çizelge 3. On altı yulaf genotipin üç lokasyondaki tane iç oranı, kavuz oranı ve protein oranı ortalama değerleri ve olușturdukları gruplar

Table 3. Mean performance and LSD ranks of 16 oat genotypes for goat percent, husk rate and protein ratio at 3 locations

\begin{tabular}{lccccccccc}
\hline & \multicolumn{3}{c}{ Tane İç Oranı (\%) } & \multicolumn{3}{c}{ Kavuz Oranı (\%) } & \multicolumn{3}{c}{ Protein Oranı (\%) } \\
\hline Genotip & Edirne & Edirne & K. eli & Edirne & Edirne & K. eli & Edirne & Edirne & K. eli \\
\hline Checota & $65.6 \mathrm{~h}$ & $67.9 \mathrm{gh}$ & $61.5 \mathrm{I}$ & $34.7 \mathrm{~b}$ & $31.6 \mathrm{c}$ & $38.2 \mathrm{a}$ & 15.2 & 11.1 & 11.3 \\
Kırklar & $70.7 \mathrm{f}$ & $72.2 \mathrm{e}$ & $71.0 \mathrm{~d}$ & $29.0 \mathrm{e}$ & $28.0 \mathrm{~d}$ & $29.0 \mathrm{f}$ & 12.6 & 10.9 & 10.7 \\
3 & $72.9 \mathrm{~d}$ & $68.5 \mathrm{fg}$ & $67.2 \mathrm{~g}$ & $26.8 \mathrm{~g}$ & $31.5 \mathrm{c}$ & $32.8 \mathrm{c}$ & 13.2 & 12.2 & 11.0 \\
4 & $72.4 \mathrm{de}$ & $65.9 \mathrm{I}$ & $66.0 \mathrm{~h}$ & $27.4 \mathrm{~g}$ & $33.9 \mathrm{~b}$ & $34.1 \mathrm{~b}$ & 13.2 & 11.8 & 10.8 \\
Kahraman & $75.4 \mathrm{ab}$ & $73.7 \mathrm{~cd}$ & $73.0 \mathrm{c}$ & $24.5 \mathrm{k}$ & $26.1 \mathrm{ef}$ & $26.8 \mathrm{~g}$ & 12.9 & 11.9 & 10.2 \\
6 & $74.8 \mathrm{bc}$ & $74.9 \mathrm{~b}$ & $73.0 \mathrm{c}$ & $25.2 \mathrm{lj}$ & $25.1 \mathrm{fg}$ & $26.9 \mathrm{~g}$ & 15.2 & 12.2 & 11.2 \\
7 & $67.2 \mathrm{~g}$ & $72.9 \mathrm{~d}$ & $70.2 \mathrm{de}$ & $32.7 \mathrm{c}$ & $26.9 \mathrm{de}$ & $29.7 \mathrm{ef}$ & 13.4 & 11.0 & 10.2 \\
Y-330 & $56.1 \mathrm{I}$ & $62.5 \mathrm{j}$ & $67.4 \mathrm{~g}$ & $43.6 \mathrm{a}$ & $37.3 \mathrm{a}$ & $32.5 \mathrm{c}$ & 13.1 & 13.1 & 9.9 \\
9 & $71.7 \mathrm{e}$ & $67.4 \mathrm{~h}$ & $67.6 \mathrm{~g}$ & $28.3 \mathrm{ef}$ & $32.6 \mathrm{c}$ & $32.4 \mathrm{~cd}$ & 13.7 & 11.5 & 9.9 \\
10 & $75.3 \mathrm{ab}$ & $73.4 \mathrm{~cd}$ & $74.5 \mathrm{~b}$ & $24.6 \mathrm{jk}$ & $26.6 \mathrm{e}$ & $25.4 \mathrm{I}$ & 12.9 & 12.4 & 9.6 \\
11 & $75.5 \mathrm{a}$ & $77.7 \mathrm{a}$ & $78.4 \mathrm{a}$ & $24.5 \mathrm{k}$ & $20.0 \mathrm{~h}$ & $21.6 \mathrm{j}$ & 14.1 & 13.5 & 9.9 \\
Sebat & $70.1 \mathrm{f}$ & $68.6 \mathrm{f}$ & $68.6 \mathrm{f}$ & $29.8 \mathrm{~d}$ & $31.4 \mathrm{c}$ & $31.5 \mathrm{~d}$ & 13.3 & 12.0 & 9.0 \\
13 & $74.3 \mathrm{c}$ & $73.5 \mathrm{~cd}$ & $73.2 \mathrm{c}$ & $25.6 \mathrm{hı}$ & $26.6 \mathrm{e}$ & $26.6 \mathrm{gh}$ & 15.1 & 13.6 & 10.7 \\
14 & $74.1 \mathrm{c}$ & $67.6 \mathrm{~h}$ & $69.8 \mathrm{e}$ & $26.1 \mathrm{~h}$ & $32.2 \mathrm{c}$ & $30.4 \mathrm{e}$ & 12.7 & 11.0 & 10.6 \\
15 & $71.8 \mathrm{e}$ & $75.5 \mathrm{~b}$ & $74.5 \mathrm{~b}$ & $28.2 \mathrm{f}$ & $24.5 \mathrm{~g}$ & $25.3 \mathrm{I}$ & 13.2 & 11.7 & 10.8 \\
16 & $72.7 \mathrm{~d}$ & $74.0 \mathrm{c}$ & $74.3 \mathrm{~b}$ & $27.2 \mathrm{~g}$ & $26.0 \mathrm{ef}$ & $25.8 \mathrm{~h}$ & 14.4 & 14.3 & 10.4 \\
Lok. Ort. & 71.3 & 71.0 & 70.6 & 28.6 & 28.8 & 29.3 & 13.6 & 12.0 & 10.4 \\
LSD & 0.68 & 0.76 & 0.88 & 0.69 & 1.26 & 0.93 & & & \\
CV (\%) & 0.67 & 0.75 & 0.88 & 1.68 & 3.06 & 2.24 & & & \\
\hline
\end{tabular}

Çizelge 4. On altı yulaf genotipine ait üç lokasyondaki olgunlașma süresi ortalama değerleri Table 4. Ripering period mean of 16 oat genotypes at 3 locations

\begin{tabular}{|c|c|c|c|c|c|c|c|c|c|c|c|}
\hline \multirow[b]{3}{*}{ Genotip } & \multicolumn{11}{|c|}{ Olgunlașma Süresi (gün) } \\
\hline & \multirow{2}{*}{$\begin{array}{c}\text { 2012-13 } \\
\text { Edirne }\end{array}$} & \multicolumn{2}{|c|}{ 2013-14 } & \multirow[b]{2}{*}{ Genotip } & \multirow{2}{*}{$\begin{array}{c}\text { 2012-13 } \\
\text { Edirne }\end{array}$} & \multicolumn{2}{|c|}{ 2013-14 } & \multirow[b]{2}{*}{ Genotip } & \multirow{2}{*}{$\begin{array}{c}\text { 2012-13 } \\
\text { Edirne }\end{array}$} & \multicolumn{2}{|c|}{ 2013-14 } \\
\hline & & Edirne & K. eli & & & Edirne & K. eli & & & Edirne & K. eli \\
\hline Checota & 29 & 36 & 39 & 7 & 33 & 37 & 42 & Sebat & 29 & 35 & 36 \\
\hline Kırklar & 36 & 36 & 43 & Y-330 & 29 & 35 & 38 & 13 & 30 & 35 & 43 \\
\hline 3 & 32 & 37 & 41 & 9 & 30 & 39 & 41 & 14 & 29 & 36 & 42 \\
\hline 4 & 31 & 37 & 42 & 10 & 38 & 35 & 40 & 15 & 36 & 36 & 43 \\
\hline Kahraman & 34 & 38 & 43 & 11 & 31 & 36 & 41 & 16 & 34 & 35 & 42 \\
\hline 6 & 29 & 33 & 39 & & & & & & & & \\
\hline
\end{tabular}

Genotiplerin olgunlașma süresi 29-43 gün arasında değișmiștir. Kırklareli lokasyonundaki genotiplerin olgunlașma süresi diğer iki lokasyondan daha uzun olmuștur. Olgunlașma süresi en uzun olarak 15 nolu hat ile Kahraman ve Kırklar çeșitleri öne çıkarken, 6 nolu hat ile Sebat çeșidi en kısa olarak öne çıkmıștır.

\section{Sonuç}

Tane verimi yönünden lokasyon ortalamalarına göre $734.8 \mathrm{~kg} / \mathrm{da}$ ile $10,728.1$ $\mathrm{kg} / \mathrm{da}$ ile 7 ve $695.6 \mathrm{~kg} / \mathrm{da}$ ile 15 nolu genotipler en yüksek tane verimine ulașmıștır. Standart çeșitlerden $690.2 \mathrm{~kg} / \mathrm{da}$ ile Kırklar ve $686.3 \mathrm{~kg} / \mathrm{da}$ ile Kahraman çeșitleri en yüksek tane verimine ulașırken, $372.1 \mathrm{~kg} / \mathrm{da}$ ile Y-330 ve $397.0 \mathrm{~kg} / \mathrm{da}$ ile Checota çeșitleri ise en düșük tane verimine ulașmıștır. İncelenen özellikler yönünden öne çıkan kısa boylu ve yatmaya dayanıklı 15 nolu hat, 2014 yllında tescile verilmiștir.

\section{Kaynaklar}

Ahmad G., Ansar M., Kalem S., Nabi G. and Hussain M., 2008. Performance of Early Maturing Oats (Avena sativa L.) Cultivars for Yield and Quality. J. Agric. Res.46(4):341-346

Anonim, 2013. Tohumluk Tescil ve Sertifikasyon Merkezi Müdürlüğü. http://www.tarim.gov.tr/ BUGEM/TTSM (Erișim Tarihi: 8.11.2017)

Anonim, 2017a.TUiK-Bitkisel Üretim İstatistikleri. http://www.tuik.gov.tr. (Erișim tarihi: 24.03.2017) Anonim, 2017b. Milli Çeșit Listesi (Tarla Bitkisi Çeșitleri) (Field Çrops). http://www.tarim. 
gov.tr/BUGEM/TTSM/Sayfalar/Detay. aspx?Sayfald=85 (Erișim tarihi: 10 Mayıs 2017)

Buerstmayr H., Krenn N., Stephan U. Grausgruber H. and Zechner E., 2007. Agronomic performance and quality of oat (Avena sativa L.) genotypes of worldwide origin produced under central European growing conditions. Field Crops Res. (101): 341-351

Colville-Baltenberger D.C., and Frey K.J., 1987. Genotypic Variability in Response of Oat to Delayed Sowing. Agron. J. 79: 813-816

Doehlert D.C., McMullen M.S., and Hammond, J.J., 2001. Genotypic and environmental effects on grain yield and quality of oat grown in North Dakota. Crop Sci. 41:1066-1072

Dumlupınar Z., 2010. Türkiye Orijinli Yerel Yulaf Genotiplerinin Avenin Proteinleri ile Morfolojik. Fenolojik ve Agronomik Özellikler Yönünden Karakterizasyonu. KSÜ Fen Bilimleri Enstitüsü Tarla Bitkileri Anabilim Dalı. Doktora Tezi. 112 s., Kahramanmaraș

Dumlupınar Z., Maral H., Yıldırım M., Gezginç H., Dokuyucu T. ve Akkaya A., 2013. Bazı Ümitvar Yulaf Hatlarının Tarımsal Özellikler Bakımından Değerlendirilmesi. Türkiye 10. Tarla Bitkileri Kongresi 10-13 Eylül, Konya. (Poster Bildiri) 121-125

Erbaș D.Ö. ve Mut Z., 2013. Saf Hat Yulaf Genotiplerinin Tarımsal ve Bazı Kalite Özelliklerinin Belirlenmesi. Türkiye 10. Tarla Bitkileri Kongresi, 10-13 Eylül, Konya, 821-828.

Food and Drug Administration, 1997. Food labeling: health claims; oats and coronary heart disease; Final Rule. Federal Register 62: 3583-3601

Gül İ., Akıncı C. ve Çölkesen M., 1999. Diyarbakır koșullarında uygun tane ve ot amaçlı yetiștirilebilecek yulaf çeșitlerinin belirlenmesi. Orta Anadolu'da Hububat Tarımının Sorunları ve Çözüm Yolları Sempozyumu. s: 117-125. 8-11 Haziran, Konya

Hoffmann L.A., 1995. World production and use of oats. In: Welch. R.W., (ed.). The Oat Crop Production and Utilization. Chapman and Hall. London. pp. 34-61

İnan A.S., Özbaș M.O. ve Çağırgan M.í., 2005. İnsan beslenmesinde kullanılan yulaf hatlarının tarımsal ve kalite özelikleri bakımından değerlendirilmesi. Türkiye VI. Tarla Bitkileri Kongresi. Cilt II: 11531155. 5-6 Eylül 2005. Antalya

Maral H., 2009. Yulaf Çeșitlerinin Azotlu Gübrelemeye Tane Verimi. Azot Kullanımı ve Verim Özellikleri Yönünden Tepkisi. K.S.Ü. Fen Bilimleri Enstitüsü. Tarla Bitkileri Anabilim Dalı. Yüksek Lisans Tezi. Kahramanmaraș. 50s

Mut Z., Akay H., Sezer İ., Gülümser A., Öner F. ve Erbașı Ö.D., 2011. Farklı Orijinli Yulaf (Avena sativa I.) Genotiplerinin Samsun Ekolojik Koșullarında Tarımsal ve Bazı Kalite Özelliklerinin Tespiti. 9. Tarla Bitkileri Kongresi 12-15 Eylül 2011 Bursa. Tahıllar ve Yemeklik Tane Baklagiller Cilt I. s.88-93

Peterson D.M., Wesenberg D.M., Burrup D.E., and Erickson C.A., 2005. Relationships among agronomic traits and grain composition in oat genotypes grown in different environments. Crop Sci. 45: 1249-1255. doi: 10.2135/ cropsci2004.0063

Tamm I., 2003. Genetic and Environmental Variation of Grain Yield of Oat Varieties. Agronomy Research. 1(1):93-97

Kahraman T., Avcı R., Öztürk İ. ve Tülek A., 2012. Trakya-Marmara Bölgesine Uygun Yulaf Genotiplerinin Belirlenmesi. Research Journal of Agricultural Sciences (TABAD) Tarım Bilimleri Araștırma Dergisi. Tarım Sempozyumu Özel Sayısı (Prof. Dr. Selahattin İptaș anısına) 5 (2): 24-28

Kahraman T., Avcı R. ve Tülek A., 2013. Yulaf (Avena sativa L.) Genotiplerinde Tane Verimi ve Bazı Kalite Özellikleri Üzerine Çeșit ve Çevrenin Etkileri. Türkiye 10. Tarla Bitkileri Kongresi 1013 Eylül. Selçuk Üniversitesi. Ziraat Fakültesi. Konya. s. 39-44

Kahraman T., Avcı R. ve Kurt C., 2015. TrakyaMarmara Bölgesinde Bazı Yulaf (Avene sativa L.) Genotiplerinin Tane Verimi. Kalite ve Tarımsal Özelliklerinin Araștırıması. 11. Tarla Bitkileri Kongresi. 7-10 Eylül. Çanakkale. s. 204-207

Kahraman T., Dumlupınar Z. ve Kurt C., 2016. Evaluation of some oat (Avene sativa L.) genotypes for yield and selected quality parameters grown under Trakya-Marmara region of Turkey. The 10th Anniversary International Oat Conference. July 11 - 15. 2016 St. Petersburg, Russia. p: 119

Kahraman T., Kurt C., Subașı A. ve Sanal T., 2017. Evaluation of Some Oat (Avena sativa L.) Genotypes in Terms of Human Nutrition Grown under Trakya-Marmara Region. 2. International Balkan Agriculture Congress. 16-18 May 2017. Tekirdağ, Turkey. p: 236

Kara R., Dumlupınar Z., Hıșır Y., Dokuyucu T. ve Akkaya A., 2007. Kahramanmaraș Koșullarında Yulaf Çeșitlerinin Tane Verimi ve Verim Unsurları Bakımından Değerlendirilmesi. Türkiye VII. Tarla Bitkileri Kongresi. 25-27 Haziran 2007, Erzurum. s.121-125

Sarı N. ve İmamoğlu A., 2011. Menemen Ekolojik Koșullarına Uygun Yulaf Hatlarının Belirlenmesi. Anadolu Ege Tarımsal Araștırma Enstitüsü Dergisi 21 (1): 16-25

Sarı N., İmamoğlu A. ve Yıldız Ö., 2012. Menemen Ekolojik Koșullarında Bazı Ümitvar Yulaf Hatlarının Verim ve Kalite Özellikleri. Anadolu (Sayı :1) 2012-18

Yağbasanlar T., Çölkesen M., ve Kırtok Y., 1990. Çukurova Koșullarında Bazı Yulaf Çeșitlerinin Bașlıca Tarımsal Özellikleri Üzerinde Bir Araștırma. Ç. Ü. Zir. Fak. Dergisi. 6(1): 95-110

Yıldız O., Sarı N., Büyükkileci C. ve İmamoğlu A., 2012. Evaluation of advanced oat lines in Aegean Region in terms of constituents affecting biscuit quality. $23^{\text {rd }}$ International Scientific-Experts Congress on Agriculture and Food Industry. September 27-29. 144 